\title{
THE QUIJINGUE METEORITE: A PALLASITE FROM BAHIA, BRAZIL
}

\section{JOSÉ MOACYR VIANNA COUTINHO*, EDUARDO BRANDAU QUITETE, MIRIAM CRUXEN BARROS DE OLIVEIRA}

\begin{abstract}
The Quijingue meteorite is a single stone of $59 \mathrm{~kg}$ found in Bahia, northeastern Brazil, sometime around 1960. It has been classified as a pallasite and contains olivine ( $\mathrm{Fa} 33$ ), iron-nickel metal (kamacite + taenite), troilite, schreibersite and chromite.

In rounded off integers, olivine $69 \%$ vol. and Ni-Fe metal $28 \%$ vol. are the major constituents regularly distributed in a "pallasitic" texture. The morphological characteristics indicate that the Quijingue stone is a "main-group" pallasite. A combination of modal and mineral analysis allowed an approximation to the meteorite real chemical composition

Keywords: meteorite, pallasite, mineralogy, chemistry

RESUMO O meteorito Quijingue é uma pedra de $59 \mathrm{~kg}$ encontrada na Bahia a cerca de 40 anos. Foi classificado como pallasito e contem olivina ( $\mathrm{Fa}_{13}$ ), metal ferro-niquel (kamacita + taenita), troilita, schreibersita e cromita. Os constituintes principais: olivina em volume de cerca de $69 \%$ e metal em cerca de $28 \%$, se distribuem regularmente na chamada textura "pallasítica". Presume-se pelas características texturais que a pedra seja um pallasito "main group". Calculou-se para este meteorito uma análise química aproximada baseada em composição modal e análise química dos componentes minerais.
\end{abstract}

Palavras - chaves : meteorito, pallasito, mineralogia, quimismo.

INTRODUCTION A single mass of the Quijingue meteorite weighing $59 \mathrm{~kg}$ was brought to the Instituto de Pesquisas Tecnológicas - IPT, in December 1998. It was said to have been discovered 35 to 40 years earlier by Mr. Atanasio Cosmo Soares (now deceased) while digging holes for fence posts around his property ("Sítio Quijingue") near the town of Quijingue, State of Bahia $\left(10^{\circ} 45^{\prime} \mathrm{S}, 39^{\circ} 13^{\prime} \mathrm{W}\right)$. The weathered stone surface is covered with pits, which delineate the previous sites of olivine crystals. A small part of the surface has been smoothed out by the continuous use of the stone as an anvil for shaping farm tools. The stone (Fig 1) was cut in three pieces at the IPT. The biggest and the smallest ones were returned to the owner. The third piece was re-cut in a $13 \mathrm{~cm}$ long plate, shown in Fig 2. A few other pieces were polished and thin sectioned for optical and electronic microscopy.

The plate, previously housed at the IPT, was donated to the Museu do Instituto de Geociências, Universidade de São Paulo. The present day owner, Mr. Aparecido Crespi (from Sāo Paulo City, Brazil) has retained the original stone weighing about $55 \mathrm{~kg}$ after cutting.

The paper describes morphological, chemical and physical features of this stone, which is admittedly the first reported pallasite found in Brazil.

STRUCTURE AND MINERALOGY The stone exhibits a convex irregular surface that was probably rounded out by weathering. No fusion crust or other flight marks were detected. A weathering rind now mantles the stone with iron enriched materials

The cut and exposed pieces became rapidly altered and developed reddish brown iron oxides at the interface of metallic and silicate components. Metal stains and darkening of yellow olivine crystals are the immediate and more visible results of the process.

The structure of the Quijingue meteorite is "pallasitic" inasmuch as it consists of "roughly equal proportions of olivine and $\mathrm{Fe}-\mathrm{Ni}$ with typical domain dimensions of about $1 \mathrm{~cm}$ " (Wasson 1974). The olivine crystals in the Quijingue pallasite are idiomorfic to somewhat rounded

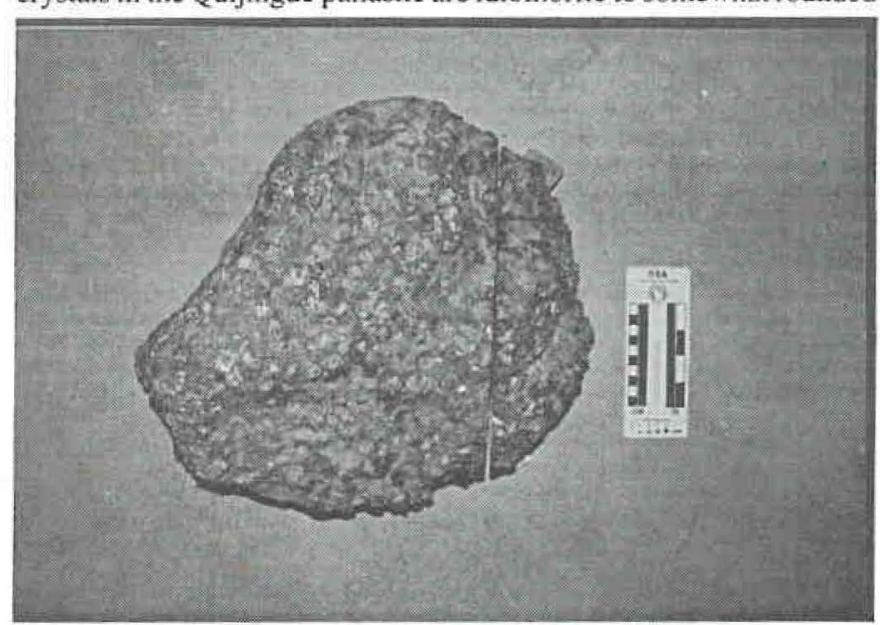

Figure I-The Quijingue meteorite sawed in three pieces. and are uniformly distributed throughout the stone. They are totally or partially enveloped by a network of metallic minerals (Fig. 2). Such a configuration is quite similar to those shown by the pallasites of Salta (Wasson 1974, fig XIV-2), Springwater (Nininger 1952, plate XIV,1) and Thiel Mountains (Dodd 1987, Fig. 7.8 a).

The modal mineral composition of the Quijingue stone was determined by counting olivine and opaque minerals found at the 0.5 spaced intersections of a quadricule printed in a transparent sheet laid over a $238 \mathrm{~cm} 2$ plate sawed from the stone. The results in volume percentage are 68.7 olivine, 25.2 kamacite, 2.6 taenite, 1.5 troilite, 1.1 schreibersite, and 0.9 chromite. SEM, transmitted and reflected light microscopy helped in the identification and estimate of the opaque and transparent minerals. Figure 3 outlines the microscopic features of olivine and metallic components in the stone.

The Quijingue pallasite exhibits a modal composition similar to several analyses made by Buseck (1977) in 30 pallasite samples from different worldwide occurrences. It compares very closely with the analysis of Ahumada, Dora, Lipovsky and South Bend samples, listed in Buseck's work.

A measured density of 4.44 determined on a $6.2 \mathrm{~kg}$ block agrees with the 4.48 calculated density, obtained by computing individual abundance and estimated specific gravity of the component phases.

The opaque minerals were studied by reflected light microscopy. Taenite occurs as thin $(0.2$ to $0.4 \mathrm{~mm})$ lamellae intergrown with kamacite. This mutual orientation is usually explained by the similarity of structural spacing and periods in both minerals. Troilite and schreibersite occur mainly as irregular masses placed between olivine and metal. Chromite occurs as rounded octahedral crystals included in metal. It is nearly opaque and transmits a deep brownish red light Olivine composition was first determined in transmitted light microscopy and was found to be Fa13 $\left(\mathrm{nx}=1.660, \mathrm{ny}=1.679, \mathrm{nz}=1.698,2 \mathrm{Vz}=85^{\circ}\right)$ This mineral crystallizes as isolated, homogeneous and undeformed individuals. The X-ray diffraction patterns confirmed the presence of

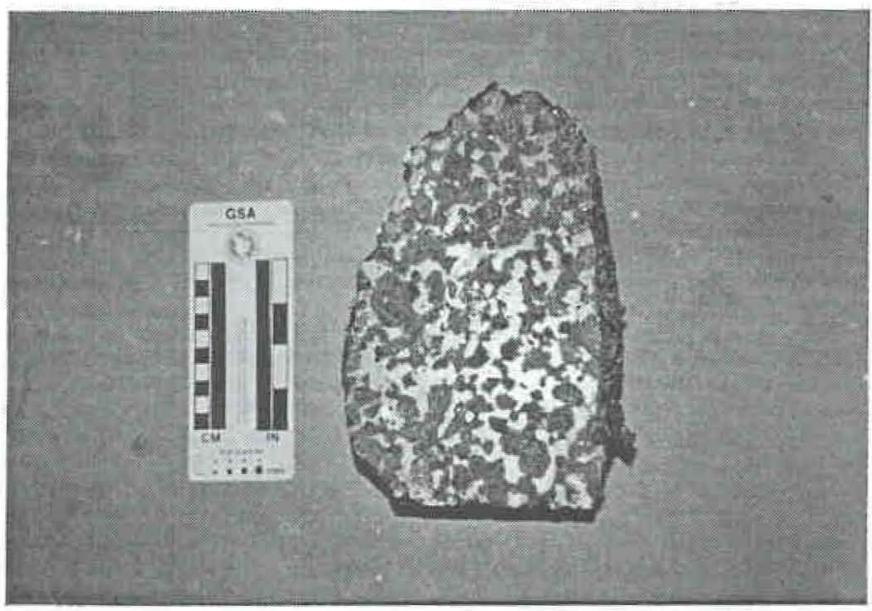

Figure 2 - A sawed slab of the meteorite. Olivine (black) and metal (white) exhibit a typical "pallasitic" texture.

* Divisão de Geologia - Instituto de Pesquisas Tecnológicas do Estado de São Paulo S. A. (IPT) P.O.Box 0141, São Paulo, Brazil 01064-970. E-mail:mlcout@mandic.com.br 


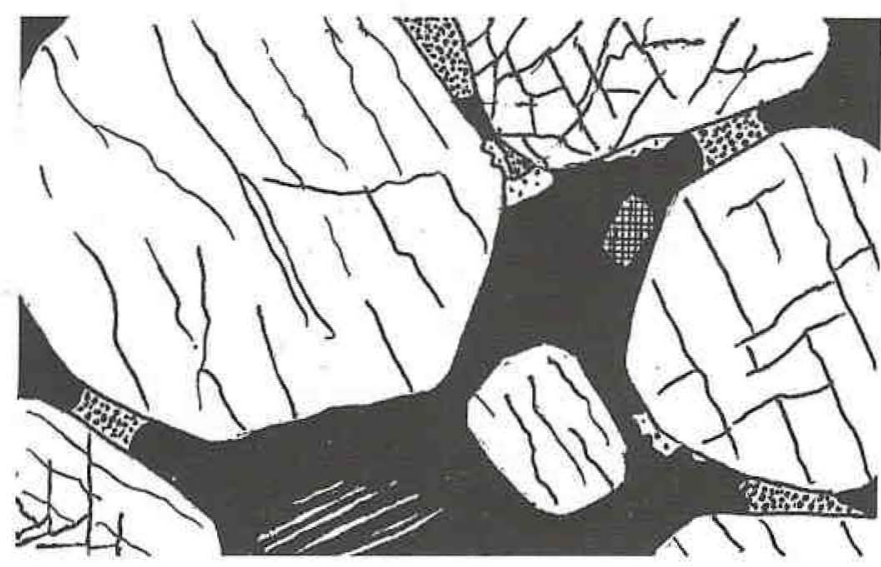

Figure 3 - Drawing based on a polished thin section showing the shapes and distribution of the meteorite constituents. Width: $2.5 \mathrm{~cm}$. Black interstitial mass: kamacite (and taenite in lamellar intergrowth, seen at lower left). Large idiomorphic crystals are olivine. Other minerals shown: troilite (heavily stippled) schreibersite (lightly stippled), chromite (checkered). Kamacite - taenite intergrowth is a feature revealed in a SEM preparation and inserted here for wholeness.

all the above mentioned minerals. It has however shown intriguing d-spacings typical of the mineral trevorite, whose presence is still under investigation.

EDS semiquantitative analyses, made in the Institute of Geosciences of the University of São Paulo, has shown that olivine is Fa13.3 (mean of 6 analyses, range of 10.6 to 16.0 ), in conformity with the optical data. The results for other components in atomic percentage computed to $100 \%$ after excluding impurities are given in Table 1.

The coarse texture of the Quijingue meteorite and the comparatively small size of the sample available, would render impractical a conventional rock chemical analysis. As suggested by Buseck, a combination of modal and mineral analysis should bypass that obstacle and give an approximation to the real chemical analysis of any homogeneously textured rock. His technique was applied to the Quijingue sample. The results are shown in Table 2 for whose preparation the following mineral densities were assumed: 3.3 olivine, 7.4 taenite, 7.2 schreibersite, 4.7 troilite, 4.9 chromite. Taking into account the volume percentage of the minerals, the resulting weight percentage (in integers) of each, is 50 olivine, 41 kamacite, 2 schreibersite, 2 troilite, and 1 chromite.

Columns A and B show that the chemical bulk composition of the Quijingue stone is similar to that of the "average pallasite" for Fe and major oxides. Variances detected in other items would be due to divergent assumptions about the content of elements in the component minerals. Columns C and D characterize the Quijingue stone (and average pallasites) by atoms and atomic ratios. They reinforce the similarities already mentioned and disclose a wide discrepancy with the ratio variations found in chondrites: $\mathrm{Fe} / \mathrm{Si} 1.08$ to 2.01 and $\mathrm{Mg} / \mathrm{Si}$
Table 1 - EDS composition of the opaque minerals found in the Quijingue meteorite

\begin{tabular}{|l|c|c|}
\cline { 2 - 3 } \multicolumn{1}{c|}{} & Mean & Range \\
\hline Kamacite & Fe: 94.2 & Fe: $93.2-94.7$ \\
(11 analyses) & Ni: 5.9 & Ni: $5.3-7.2$ \\
\hline Taenite & Fe: 81.2 & Fe: $81.0-81.4$ \\
(2 analyses) & Ni: 18.8 & Ni: $18.5-19.1$ \\
\hline Schreibersite & Fe: 51.4 & Fe: $53.3-49.0$ \\
(2 analyses) & Ni: 24.3 & Ni: $25.9-22.7$ \\
& P: 24.5 & P: $20.8-28.3$ \\
\hline Troilite & Fe: 50.6 & Fe: $47.7-55.9$ \\
(5 analyses) & S: 49.4 & S: $44.1-42.3$ \\
\hline Chromite & Fe: 22.9 & - \\
(one analysis) & Al: 10.1 & \\
& Mg: 12.7 & \\
& Cr: 54.3 & \\
\hline
\end{tabular}

Table 2 - Pallasite chemical compositions

\begin{tabular}{|c|c|c|c|c|c|}
\hline & $\mathrm{A}$ & B & & $\mathrm{C}$ & $\mathrm{D}$ \\
\hline $\mathrm{SiO}_{2}$ & 20.6 & 19.7 & $\mathrm{Si}$ & 9.6 & 9.2 \\
\hline $\mathrm{Al}_{2} \mathrm{O}_{3}$ & 0.3 & n.d. & $\mathrm{Al}$ & 0.2 & n.d. \\
\hline $\mathrm{Cr}_{2} \mathrm{O}_{3}$ & 1.1 & 0.2 & $\mathrm{Cr}$ & 0.7 & 0.1 \\
\hline $\mathrm{MgO}$ & 25.7 & 21.0 & $\mathrm{Mg}$ & 15.4 & 12.6 \\
\hline $\mathrm{FeO}$ & 3.3 & 6.1 & $\mathrm{Fe}$ & 46.5 & 49.1 \\
\hline $\mathrm{Fe}$ & 43.9 & 44.4 & $\mathrm{Ni}$ & 3.9 & 5.7 \\
\hline $\mathrm{Ni}$ & 3.9 & 5.7 & $\mathrm{P}$ & 0.5 & 0.3 \\
\hline$S$ & 0.7 & 2.2 & $S$ & 0.7 & 2.2 \\
\hline $\mathrm{P}_{2} \mathrm{O}_{5}$ & n.d. & $<0.1$ & 0 & 22.5 & 20.8 \\
\hline $\mathrm{P}$ & 0.5 & 0.3 & $\mathrm{Fe} / \mathrm{Si}$ & 4.84 & 5.33 \\
\hline Co & n.d. & 0.2 & $\mathrm{Mg} / \mathrm{Si}$ & 1.60 & 1.37 \\
\hline
\end{tabular}

A - Quijingue pallasite, calculated from mode (this paper). $B$ - "Average pallasite ", calculated from 30 modes (in Buseck 1977). C - Quijngue pallasite, composition by elements and selected atomic ratios. D - "Average pallasite", composition by elements and selected atomic ratios

0.63 to 0.93 as listed in Dodd (1981). Such disagreement is rather enigmatic since the presence of abundant olivine in pallasites suggests kinship to stony meteorites, specifically chondrites.

The overall mineral and textural characteristics of the Quijingue stone point to a strong analogy to the "main-group" pallasites. However, as remarked by Dodd (1981), the most reliable basis for pallasite classification is the distribution of trace elements in metal. Such an investigation together with age determination is under way at the Universidade de São Paulo.

\section{References}

Buseck P.R. 1977. Pallasite meteorites-mineralogy, petrology and geochemistry. Geochim. Cosmochim Acta, 31:711-740

Dodd R. T. 1981. Meteorites, Cambrige Univ. Press, 368 pp.

Nininger H. H. 1952. Out of the Sky. Dover Publications Inc., 355 pp

\section{Wasson J. T. 1974. Meteorites. Springer-Verlag, $316 \mathrm{pp}$} Manuscrito NB-20
Recebido em 20 de julho de 1999 Revisão dos autores em 15 de agosto de 1999 Revisão aceita em 20 de agosto de 1999 